\title{
Digitainability and Financial Performance: Evidence from the Serbian Banking Sector
}

\author{
Nikola Stefanovic ${ }^{1, * \mathbb{D}}$, Lidija Barjaktarovic ${ }^{1}$ and Alexey Bataev ${ }^{2} \mathbb{D}$ \\ 1 Faculty of Business, Singidunum University, 160622 Beograd, Serbia; lbarjaktarovic@singidunum.ac.rs \\ 2 Graduate School of Public and Financial Management, Petersburg Polytechnic University, \\ 195251 St. Petersburg, Russia; bataev_av@spbstu.ru \\ * Correspondence: nstefanovic@singidunum.ac.rs
}

Citation: Stefanovic, $\mathrm{N}$

Barjaktarovic, L.; Bataev, A.

Digitainability and Financial Performance: Evidence from the Serbian Banking Sector. Sustainability 2021, 13, 13461. https://doi.org/ $10.3390 /$ su132313461

Academic Editor: Giuliana Birindelli

Received: 6 November 2021

Accepted: 22 November 2021

Published: 6 December 2021

Publisher's Note: MDPI stays neutral with regard to jurisdictional claims in published maps and institutional affiliations.

Copyright: (c) 2021 by the authors. Licensee MDPI, Basel, Switzerland. This article is an open access article distributed under the terms and conditions of the Creative Commons Attribution (CC BY) license (https:/ / creativecommons.org/licenses/by/ $4.0 /)$.

\begin{abstract}
This study aimed to explore the cross-section of digitalization and sustainability in banking and its effect on bank performance. The sample consisted of all of the banks $(n=25)$ operating in the Republic of Serbia from 2011 to 2020. The research results show that the banks focusing on digitalization and sustainability are profitable, even in the face of coronavirus disease 2019 (COVID-19). Furthermore, using the Pearson's correlation, the study shows that the level of investment in digital transformation has a strong relationship with the net result. We advocate that digitainability in banking is an important factor in uncertain times and should be fostered and included in bank strategies in the post-COVID 19 world. To the best of our knowledge, this is the first study that provides insight into digitainability and bank performance.
\end{abstract}

Keywords: digitainability; commercial banks; digitalization; sustainability; performance

\section{Introduction}

The cross-section of digitalization and sustainability (digitainability) has been neglected by academic research, although digitainability offers a great opportunity to capture the cross-fertilization effects of both digitalization and sustainability [1]. Digitainability is a relatively new concept, and it focuses on digitally sustainable societies or the promotion of sustainable societies through the use of digitalization [2].

Previous studies in the banking field have mostly investigated the relationship between digitalization and banking or the relationship between sustainability and banking. The studies focusing on the link between digitalization and banking show that digitalization is of special importance to banking [3], as it is a continuous and unstoppable process $[2,4]$. The research also reports that digitalization can increase productivity and decrease costs [5], thus leading to better performance. A study focusing on single countries, such as Nigeria, shows that digitalization, if adequately implemented, has a positive impact on the performance of commercial banks [6], whereas a study in China showed that investment in digitalization contributes to sustainable production improvements in commercial banks [7]. On the other hand, the research reports that digitalization does not come free of operational risks [8] and that the digitization of banking poses a threat to several areas, including security [9]. Accordingly, innovation, willingness to take risks, and being ahead of competition should all be parts of successful digitalization [10]. Although the link between digitalization and banking has been identified, the data on the effects of digitalization on financial performance in banking are still limited, especially in developing markets.

Studies focusing on the link between sustainability and banking (ignoring the effects of digitalization) indicate that in certain countries, such as Bangladesh, sustainable banking is on the front lines of sustainable development [11], whereas in other countries, such as India, the banking sector has responded to sustainability issues slowly [12]. In Poland, national banks and government-owned banks have demonstrated a greater commitment 
to sustainability than foreign banks [13]. As far as performance is concerned, in China, research shows that corporate sustainability (CS) and financial performance correlate to each other positively [14], whereas in Islamic banking, the research implies that improvements in sustainability practices add financial value to various stakeholders [15]. The crossregional study shows that sustainable banking practices increase profitability [16], whereas a previous study examining 235 European banks from 2007 to 2016 showed that there is a positive impact of environmental, social, and governance (ESG) issues on performance [17]. Research focusing on 472 global banks by considering the period from 2015 to 2019 shows that ESG initiatives are perceived as strong value-adding mechanisms [18]. Although the link between sustainability and performance has been identified, the data on the effects of sustainability on financial performance are limited, especially in developing markets.

Considering the effects of both digitalization and sustainability, very few studies focus on its cross-section. The research focusing on CS and digitalization in international banks suggests that the cross-section of CS and digitalization leads to banks demonstrating better market performance and efficiency [19] and that the reputation that is generated by CS offsets many digitalization drawbacks [20]. Clients being at the core of banking strategy now more than ever has led to the introduction of fintech [21], resulting in some of the current trending topics for banks being fintech and coronavirus disease 2019 (COVID-19) [22]. Overall, it appears that the association between digitalization and sustainability in banking has not been extensively studied, especially not during the COVID-19 pandemic, which accelerated the pace of digitalization [7], and considering the limited findings from the already very limited literature, we focused on the cross-section of digitalization and sustainability and its effect on bank performance in a developing country in the Western Balkan region by capturing the first phase of the COVID-19 pandemic.

The existing studies discussing the banking sector of the Western Balkan region (i.e., Albania, Bosnia and Herzegovina, Montenegro, North Macedonia, Serbia) confirmed the following: (1) the Serbian banking sector is the most developed, and 7 out of the top 10 banks in the region, as determined with respect to banking assets, are located in Serbia [23]; (2) Serbian citizens make digital payments more than the global average (78\% vs. $45 \%$ ) [24]; and (3) Serbia is working on pre-accession agreements with the European Union (EU) [25] in order to become a member. Accordingly, the focus of the present study is the Serbian banking sector since the findings that are discussed here can be applied to the rest of the Western Balkan region, and future research studies can be compared with the trends in the EU. According to the authors' findings, there is no research related to the digitainability and profitability of the banking sector in the Western Balkan region. At the same time, it is an important topic for all banks until 2023, which is when it will become the responsibility of the banks to report to the appropriate supervisory bodies [22].

Finally, the purpose of this research is to assess the development of digitalization, sustainability, and the overall trends in the Serbian banking sector from 2011 to 2020 and to determine its digitainability characteristics. The aim of the paper is to determine whether there is a link between the digitainability and profitability of Serbian banks and to extend the current literature. Moreover, the goal of the present study is to propose new strategies during the new normal, the third phase of the COVID-19 crisis [26], which has redefined the entire world. COVID-19 has been described as the new black swan [27] in the international economy, and it has had a substantial influence on the improvement of the following: (1) risk management strategies undertaken by enterprises to obtain and maintain the stability in the market (at the micro and macro levels), which means the application of an overall risk management approach (especially with respect to the pandemic and security); (2) corporate governance in all types of companies, regardless of the ownership structure; (3) the application of the best practices in the internal control and audit systems; and (4) compliance and fraud detection (especially with respect to anti-money laundering and terrorist financing) [28].

The present study represents the continuation of the research performed in 2018/2019, which was focused on the digital transformation of the Serbian banking sector and invest- 
ment in digitalization (shown as the intangible investments affecting the net result of the banking sector). The results of the $2018 / 2019$ research confirmed that (1) there is a link between the money invested in digitalization and the results that are achieved through relevant financial indicators, i.e., the intangible assets and net profit of the analyzed banks, individually and overall, and (2) the banking offer of alternative distribution channels in Serbia can be considered to be developed [29].

Considering the subject and aims of the research, the main hypothesis of the research is as follows:

Hypothesis 1 (H1). The level of investment in digital transformation has a strong relationship with the net result of the Serbian banking sector.

The additional research hypotheses are:

Hypothesis 2 (H2). The Serbian banking sector exhibits characteristics of digitainability.

Additionally,

Hypothesis 3 (H3). Serbian banks focusing on digitainability are profitable.

The article consists of four parts. Section 1 is an introduction to the article, and Section 2 is the methodology of the paper. Section 3 reveals the results of the research and discusses the major findings of the article (the results of the study are of importance to both academics and practitioners). Section 4 presents the conclusion of the paper.

\section{Materials and Methods}

Our study consisted of all of commercial banks $(n=25)$ operating in the Republic of Serbia as of 31 March 2021 [30]. The data were collected from the publicly disclosed reports and websites of the commercial banks [31-56] and the National Bank of Serbia (NBS).

The following banks were the subjects of the analysis [52]: Addico Bank a.d. Beograd (Addico), Agroindustrijsko komercijalna banka AIK a.d. Beograd (AIK), ALTA banka a.d. Beograd (which, by the end of 2019, operated as Jubmes banka a.d. Beograd) (ALTA), Api Bank a.d. Beograd (API), Banca Intesa a.d. Beograd (Intesa), Bank of China a.d. Srbija (Bank of China), Banka Poštanska štedionica a.d. Beograd (Postanska), Crédit Agricole banka Srbija a.d. Novi Sad (Credit Agricole), Direktna banka a.d. Kragujevac (Direktna), Erste bank a.d. Novi Sad (Erste), Eurobank a.d. Beograd (Euro), Expobank a.d. Beograd (Expo), Halkbank a.d. Beograd (Halk), Komercijalna banka a.d. Beograd (Komercijalna), Mirabank a.d. Beograd (MIRA), MOBI banka a.d. Beograd (which, until 10 October 2019, operated as Telenor banka a.d. Beograd) (MOBI), MTS banka a.d. Beograd (MTS), NLB banka a.d. Beograd (NLB), Opportunity banka a.d. Novi Sad (Opportunity), OTP banka Srbija a.d. Novi Sad (OTP), ProCredit bank a.d. Beograd (ProCredit), Raiffeisen bank a.d. Beograd (Raiffeisen), Sberbank Srbija a.d. Beograd (Sber), Srpska bank a.d. Beograd (Srpska), and UniCredit bank Srbija a.d. Beograd (UniCredit). According to the available information, 2 banks are virtual (MOBI and MTS), and 23 banks were considered traditional commercial banks.

The previous research included 27 banks [29], all of which performed business at the end of Q1 2019. Since then, three banks have become integrated with each other, namely OTP, Societe Generale banka Srbija a.d. Beograd (Societe General), and Vojvođanska banka a.d. Novi Sad (Vojvođanska), and they have continued to operate under the name of OTP. Moreover, two banks changed their names (Jubmes banka a.d. Beograd and Telenor banka a.d. Beograd), and they have continued to cooperate as ALTA and MOBI.

The period of the analysis was from 2011 to 2020. We added the data for the last quartile of 2018 and FY 2019 and 2020, which was affected by COVID-19, compared to the initial research [29]. In the meantime, the Serbian banking sector implemented some of the pillars of Basel III and placed special attention on the security of information systems, 
customer data protection, strength activities on business continuity, and a better pandemic risk management strategy [57].

The starting points in the analysis are the same indicators that were the subject of the previous research [29], and the following balance sheet indicators were analyzed: the intangible assets and the net result expressed in RSD. The intangible assets, which consist of software, intangible assets under preparation, and licenses, were linked to digitalization and information technology (IT). The net profit was selected as the key indicator to demonstrate the performance of banks as the banks tried to achieve optimal results (or the right measure between investment and returns).

To determine the degree of interconnectedness of the indicators (the intangible assets and the net profit), SPSS software was used to calculate the correlation coefficient. In the current study, we used Pearson's correlation coefficient to determine the connection.

The Pearson's correlation coefficient was calculated according to the following formula [29]:

$$
r=\sum_{i=1}^{n}\left(x_{i}-\bar{x}\right)\left(y_{i}-\bar{y}\right) / \sqrt{ } \sum_{i=1}^{n}\left(x_{i}-\bar{x}\right)^{2} \sqrt{ } \sum_{i=1}^{n}\left(y_{i}-\bar{y}\right)^{2}
$$

where $n$ is the number of indicators in the relationship; $x_{i}$ is the independent indicator; $y_{i}$ is the dependent indicator; and $\bar{x}$ and $\bar{y}$ are the averages (of the relevant indicators).

The Pearson's correlation values exhibit the following: (1) \pm 0 to \pm 0.2 (no relationship), (2) \pm 0.21 to \pm 0.4 (weak relationship), (3) \pm 0.41 to \pm 0.6 (mid-relationship), (4) \pm 0.61 to \pm 0.8 (strong relationship), and (5) \pm 0.81 to \pm 1 (very strong relationship).

In the present study, there are two indicators $(n)$ : (1) the intangible assets are the dependent indicator $\left(y_{i}\right)$, and (2) the net profit is the independent indicator $\left(x_{i}\right)$.

Considering that all Serbian banks invested heavily in digitalization during the COVID-19 pandemic [58], new research elements were added: (1) the calculation of average Return on Equity (ROE) and the average Return on Assets (ROA) for all banks, both individually and overall (the outliers were excluded from the calculation, which were mostly related to the integration processes or big credit frauds), with a distinction between virtual and traditional, as described for the EU in the primary research by Amaboldi and Clayes presented in the article by Zelenovic et al. [59]; the following formulas were applied for the profitability indicators: $\mathrm{ROE}=$ Net Income/Total Equity and ROA $=$ Net Income/Total Assets; the average was calculated by applying the arithmetic mean; (2) to determine the sustainability of Serbian banks, data were obtained from their websites, the UN Global Compact-Network Serbia website [60], and ASB Banking [58]; (3) the examination of digitainability in banks in the Republic of Serbia was determined on the basis of crossing the data related to the digital product offer and sustainability data; and (4) the inquiry of banks focusing on digitainability but that are also profitable was determined on the basis of cross analyzing data related to the digitainability and average ROE for the analyzed period. Tables that are related to digital banking product offers and their sustainability are posted in Appendix A.

\section{Results and Discussion}

Since 2001, there has been a clear diminishing trend in the number of banks in Serbia. Accordingly, as previously mentioned, there were 27 banks in the first quartile of 2019 [29], and according to the data from the NBS [56], there were 25 banks at the end of 2020. Furthermore, the NBS approved four mergers in the local market: (1) NLB and Komercijalna - their integration process started at the end of 2020, (2) Postanska and MTStheir integration process started on 30 June 2021, (3) Raiffeisen and Credit Agricole-their integration process started in the second half of 2021, and (4) Euro and Direktna-their integration process started in the second half of 2021.

Compared to the previous research, the characteristics of the Serbian banking sector were similar with respect to the ranking and ownership structure of the banks (banks with foreign capital were dominant). The biggest market share belonged to Intesa (15\%), UniCredit (12\%), and Komercijalna (10\%). If the first five banks in the Republic of Serbia are taken into consideration (Intesa, UniCredit, Komercijalna, OTP, and Raiffeisen), using 
the amount of the assets, loans placed, and deposits collected, they constituted more than a half of the banking sector of the Republic of Serbia. The first 10 banks had participation in assets, total gross loans, and deposits near $80 \%$. The net result of the banking sector increased, and the profitability indicators were maintained at the same level [30].

The previous study [29] confirmed that all Serbian banks developed alternative distribution channels, i.e., all of them had electronic banking (e-banking, m-banking, online banking, home banking, e-commerce, 24/7 payment zones), payment cards (types: debit and credit-DINA, VISA, Master, American; POS, ATM, payment method), and they were participants in the NBS instant payment system (NBS IPS), which was introduced on 22 October 2018. It can be said that all of the Serbian banks (100\%) were using some form of digitalization. The following banks were able to offer more products: Addico, Erste, Expo, Komercijalna, Telenor (now MOBI), NLB, OTP (including Societe General and Vojvođanska), ProCredit, Raiffeisen, Sber, and UniCredit.

Appendix A, Table A1 provides information about new digital banking products that became available in the Republic of Serbia in the first quartile of 2021. In the column "In cooperation with non-banking partners," the information that is provided is about the expended offer thanks to the following: (1) UnionPay-a Chinese financial services corporation that provides bank card services (this means that retail customers, owners of the UnionPay cards, are able to withdraw money at ATMs in Serbia, i.e., ATMs of those banks that concluded an agreement with the Chinese partner); (2) PayPal—an American fintech company that specializes in online money transfers worldwide (this means that retail customers, owners of Visa or Master card, can withdraw money from ATMs in Serbia belonging to those banks who have concluded an agreement with the American partner); (3) Apple Pay-this allows owners of Apple devices to execute payments with particular banks; (4) MoneyGet-an international ATM network that was established by the company Payten (a part of Asseco South Eastern Europe, a leading IT company in the area of software solution production and implementation in the finance industry), which is in the function of development and support of the payment industry. Payten partners (commercial banks) can offer their retail customers the ability to withdraw cash without additional costs; and (5) payment institutions-participants in the financial market who offer payment services - this means that banks that have concluded an agreement with payment institutions are their representatives with respect to payment transactions within the country and abroad.

It should be noted that the information regarding digital banking offers and customer experience with these offers vary in quality. However, the following are common facts about these digital banking offers: (1) they resulted in an increased number of customers choosing to use digital banking products and (2) resulted in the permanent improvement of digital services and in the introduction of new ones in accordance with customer needs and with respect to the security of their data and transactions. Technologically, three banks are more advanced than the others: Intesa, ProCredit $(100 \%$ of transactions by their customers are digitally performed), and Raiffeisen. All of them provide customers with the possibility of executing payments/digital banking products through the use of Apple devices. It should be noted that there is an increased number of banks offering online cash credits and online communication with personal bankers.

The following banks have digital banking product offers than average: Intesa, ProCredit, Raiffeisen, OTP, Erste, Euro, AIK, Direktna, MOBI, Postanska, Komercijalna, NLB, Addico, Halk, Sber, and UniCredit. Unfortunately, it can be concluded that banks that do not have well-developed digital banking products are as follows: Bank of China, MIRA, and Srpska.

It can be also noticed that the NBS plays a significant role in promoting/supporting and pushing digital products, especially with respect to IPS (18 banks, including 3 banks that have a wider offer for entrepreneurs and SME's-Intesa, UniCredit, and Euro) and UnionPay (12 banks). Furthermore, the regulation and supervision of payment institution businesses by the NBS has a significant number of concluded contracts between banks and 
payment institutions (18). For retail customers, it is important that their money transactions are able to be executed securely. Therefore, the role of the NBS is very important, especially with respect to security in the financial sector.

Generally, we can say that there is a trend of cooperation with other non-banking partners to expand banking offers for customers:

(1). Ownership structure-shareholders are come from (a) different industries, such as telecommunication, insurance, investment funds, micro-finance institutions, institutions that finance green and sustainable projects, brokerage houses, consultants focused on providing data, and payment institutions. MOBI stresses the synergetic effect of their customer experience as their advantage because they offer the best in terms of both banking and telecommunication. MTS emphasizes the synergetic offers from the insurance and telecommunication industries as their advantage. Opportunity is focused on a targeted group of customers who find it difficult to obtain financial services from traditional banks. (b) Shareholders also come from different holding structures who come from the financial industry to obtain proper tax treatment.

(2). The IT industry (Asseco SEE) offers new products for retail customers, and bank partners are ready to promote it, which is the case for products such as MoneyGet.

(3). Fintech industries, such as PayPal.

Therefore, all stakeholders are interested in (1) selling more products to existing customers, (2) acquiring new clients, and (3) generating additional profits.

In the next step, we determined which banks has a sustainable business model that takes care of all of the necessary stakeholders. Appendix A, Table A2 summarizes sustainable banks in the Republic of Serbia who are in accordance with data equality. It can be concluded that 18 ( 1 virtual and 17 traditional) out of the 25 Serbian banks (72\%) focus on sustainability: Intesa, Erste, ProCredit, UniCredit, Opportunity, OTP, MOBI, NLB, Raiffeisen, Addico, ALTA, Credit Agricole, Direktna, Euro, Halk, Komercijalna, AIK, and Bank of China. The majority of those (almost 11,61\%) banks respect the UN Global Compact Principles [60]:

- Nine are part of the UN Global Compact-Network Serbia (Intesa, Erste, OTP, Addico, ALTA, Credit Agricole, Direktna, Euro, and Komercijalna).

- Two clearly emphasize that they respect the UN sustainability principles [50] (UniCredit and Opportunity).

Furthermore, three banks have a transparent Code of Ethics (Intesa, ProCredit, and UniCredit), whereas seven banks have a unique approach to sustainability: (1) respecting Global Alliance for Banking on Values (planet, people, and prosperity) (Opportunity),

(2) Corporate Social Responsibility, which includes Corporate Responsible Strategy (Erste),

(3) Social Responsible Banking with special attention placed on an environmental approach (ProCredit), (4) an ESG committee on the holding level and in cooperation with UNICEF on the local level (UniCredit), (5) human banking (MOBI), and (6) two banks support competition in organic production (NLB) and acts as a generator for new ideas (OTP). Based on previous data, it can be concluded that $72 \%$ of the banks in the Serbian banking sector have a digitainability characteristic; thus, $\mathrm{H} 2$ is confirmed.

In the following step, the intangible investments and the net result of the banking sector were analyzed. As in the previous study, these were the only the quantitative publicly disclosed data that were essentially be accompanied by IT, innovation, digitization, and risk management. The limitations of the study were the same: (1) the non-material investment in the Serbian banking sector exclusively contains aggregate categories of software, licenses, and intangible investments that are in preparation; (2) there is a lack of information determining the activity of internationally active banks (which have leasing companies as their daughter enterprises) for which hardware and licenses are on the books of the related parties; (3) there is no continuity in the number of banks that are the subject of the analysis as the result of mergers, acquisitions, green-field investments, the liquidation 
of the state banks, and the sale of domestic private banks. The results of the analysis are shown in Table 1.

Table 1. Correlation coefficient of intangible investments and net result of the banking sector from 2011 to 2020.

\begin{tabular}{cccccccccccc}
\hline Banking sector & 2011 & 2012 & 2013 & 2014 & 2015 & 2016 & 2017 & 2018 & 2019 & 2020 \\
\hline Correlation coefficient & 0.4968 & 0.5548 & 0.3172 & 0.2114 & 0.4347 & 0.5169 & 0.584 & 0.7135 & 0.6614 & 0.6258 \\
\hline \multicolumn{1}{c}{ Source: Authors' calculations based on the NBS data [30]. } &
\end{tabular}

The obtained results show that there is a direct relationship between the intangible investments and net results; that is, when the value of intangible assets increases, the net result is increased, and vice versa. Accordingly, the level of investment in digital transformation has a mid-relationship with the net result of the banking sector of the Republic of Serbia. Compared to the previous study, it should be noted that since 2018, there has been a strong relationship between digital transformation investments and the achieved financial result. This is the result of the previous actions taken to be competitive in the market and of the new challenges caused by COVID-19 to obtain satisfaction and security customer security at the same time; thus, H1 is confirmed. The results of the further analysis are shown in Table 2.

A very strong relationship exists between the intangible investments and the net result for Halk. A strong relationship exists between the analyzed indicators between Komercijalna, MIRA, AIK, and Opportunity. A medium relationship exists between the analyzed indicators for ALTA, Intesa, NLB, UniCredit, MOBI, Bank of China, OTP, Addico, Sber, and Expo. A weak relationship exists between the analyzed indicators for Raiffeisen and Postanska. There is no relation between the analyzed indicators for Euro, Credit Agricole, MTS, Erste, Direktna, API, Srpska, and ProCredit. Based on the values of the correlation coefficient, it can be concluded that investments in digitalization, innovation, and IT technology have a strong degree of connectiveness with the results achieved in the Serbian banking sector.

Compared to the previous study, it can be concluded that:

(1). Three banks increased the correlation between investment in intangible assets and net profit (Halk, Addico, and Banca Intesa), with two of them being profitable (67\%)—this represents the smallest group of banks;

(2). Thirteen banks have the same correlation values (Komercijalna, MIRA, Expo, NLB, OTP, Sber, MOBI, Postanska, ProCredit, MTS, Euro, Direktna, and API), with six of them being profitable (46\%) - it is the biggest group of banks;

(3). Nine banks showed a decrease in the significance between investment in intangible assets and net profit (AIK, Opportunity, Bank of China, ALTA, UniCredit, Raiffeisen, Srpska, Erste, and Credit Agricole), with seven of them being profitable (78\%)-the represents the second largest group of banks. At the same time, it is also the group with the highest number of profitable banks. This is the reason why H3 will be tested (as previously mentioned, ProCredit stresses that their transactions are 100\% digitalized, so it will be confirmed as to whether these banks are profitable).

With respect to profitability, it can be concluded that traditional Serbian banks are more profitable than virtual ones. However, both types of Serbian banks are far away from those of the EU and from the specific countries that are members of the EU (Table 3). There is also space for further improvement in terms of cost efficiency. 
Table 2. Correlation coefficient of intangible investments and net result of banks (including average profitability ratios) from 2011 to 2020. (banks exhibiting digitainability characteristics are marked with *).

\begin{tabular}{|c|c|c|c|c|c|}
\hline \multirow[t]{2}{*}{ No. } & \multirow[t]{2}{*}{ Bank } & \multirow[t]{2}{*}{ Correlation Coefficient } & \multirow{2}{*}{$\begin{array}{l}\text { Change Compared to the } \\
\text { Previous Research }(\uparrow,=, \downarrow)\end{array}$} & \multicolumn{2}{|c|}{ Profitability (\%) } \\
\hline & & & & ROE & $\mathrm{ROA}$ \\
\hline 1. & Halk * & 0.8641 & $\uparrow$ & 1.06 & 0.19 \\
\hline 2. & Komercijalna * & 0.7820 & $=$ & 5.11 & 0.93 \\
\hline 3. & MIRA & -0.7629 & $=$ & -14.73 & -6.05 \\
\hline 4. & AIK * & 0.7348 & $\downarrow$ & 9.47 & 2.65 \\
\hline 5. & Opportunity * & 0.6485 & $\downarrow$ & 9.3 & 1.70 \\
\hline 6. & ALTA * & 0.5811 & $\downarrow$ & -2.64 & -0.83 \\
\hline 7. & Intesa * & 0.5338 & $\uparrow$ & 9.67 & 1.94 \\
\hline 8. & NLB * & 0.5298 & $=$ & -20.24 & -3.48 \\
\hline 9. & UniCredit* & 0.5069 & $\downarrow$ & 9.91 & 1.92 \\
\hline 10. & MOBI * & 0.4715 & $=$ & -27.13 & -8.86 \\
\hline 11. & Bank of China * & 0.4646 & $\downarrow$ & -4.77 & -2.54 \\
\hline 12. & OTP * & 0.4424 & $=$ & -0.52 & -0.17 \\
\hline 13. & Addico * & 0.4372 & $\uparrow$ & -2.42 & -0.53 \\
\hline 14. & Sber & -0.4290 & $=$ & 3.91 & 0.92 \\
\hline 15. & Expo & -0.4276 & $=$ & -7.91 & -0.67 \\
\hline 16. & Raiffeisen bank * & 0.3937 & $\downarrow$ & 10.18 & 2.32 \\
\hline 17. & Postanska & 0.2267 & $=$ & 3.06 & 0.65 \\
\hline 18. & Euro * & -0.2086 & $=$ & 3.01 & 0.92 \\
\hline 19. & Credit Agricole * & 0.1168 & $\downarrow$ & 2.85 & 0.29 \\
\hline 20 & MTS & -0.0956 & $=$ & -12.72 & -3.07 \\
\hline 21 & Erste * & 0.0951 & $\downarrow$ & 8.00 & 1.08 \\
\hline 22. & Direktna * & 0.0610 & $=$ & 1.67 & 0.37 \\
\hline 23. & API & 0.0606 & $=$ & -13.59 & -1.89 \\
\hline 24. & Srpska & 0.0219 & $\downarrow$ & 1.18 & -0.98 \\
\hline 25. & ProCredit* & -0.0046 & $=$ & 11.39 & 1.82 \\
\hline
\end{tabular}

Source: Authors' calculations based on the NBS data [29,30].

Table 3. Profitability comparison of Serbian banks (average 2011-2020) and the EU banks.

\begin{tabular}{cccccccc}
\hline \multirow{2}{*}{ Type of the Bank } & \multicolumn{2}{c}{ Serbian } & \multicolumn{2}{c}{ EU Average } & \multicolumn{3}{c}{ EU Spread between Countries } \\
\cline { 2 - 9 } & ROA (\%) & ROE (\%) & ROA (\%) & ROE (\%) & ROA (\%) & ROE (\%) \\
\hline Traditio al & -0.18 & 0.99 & 0.63 & 12.39 & $0.19-0.96$ & $6-18.70$ \\
\hline Virtual & -5.96 & -19.92 & 0.76 & 10.51 & $0.17-2.66$ & $4.90-21.29$ \\
\hline
\end{tabular}

Source: Authors' calculation based on data available on Serbian bank websites [59].

It can be noticed that 15 traditional banks, i.e., $60 \%$ of the Serbian banking sector (where 12 have bank digitainability characteristics (in italic) and where seven of them are ranked in the list of top 10 banks according to the NBS (in italic and market with ${ }^{* \prime \prime}$ at the same time)), have a positive ROE (average for the analyzed period): ProCredit, Raiffeisen*, UniCredit*, Intesa*, AIK*, Opportunity, Erste*, Komercijalna*, Sber, Postanska, Euro* Credit Agricole, Direktna, Srpska, and Halk. Therefore, Serbian banks focusing on digitalization and sustainability are profitable. Further findings are in line with this. 
Serbian banks focusing on digitainability (which are profitable) are in the no-relationship group (shown in Appendix A, Table A3; the key findings are shown in Table 4), i.e., ProCredit, Erste, Euro, Credit Agricole, and Direktna. Second, there are banks with a strong relationship (Opportunity, Komercijalna*, and $\mathrm{AIK}^{*}$ ). Third, there are banks with a medium relationship (UniCredit* and Intesa*). Finally, there are banks with a weak (Raiffeisen ${ }^{*}$ ) and a very strong relationship (Halk). It can be concluded that with respect to digitainability and profitability, the ranking of the banks can be expressed as follows: ProCredit, Raiffeisen*, UniCredit*, Intesa*, AIK* Opportunity, Erste* ${ }^{*}$ Komercijalna*, Euro* Credit Agricole, Direktna, and Halk; thus, $\mathrm{H} 3$ is confirmed.

Table 4. Profitability ranking of Serbian banks focusing on digitainability.

\begin{tabular}{ccccc}
\hline No. & $\begin{array}{c}\text { Banks Focusing on } \\
\text { Digitanibility }\end{array}$ & $\begin{array}{c}\text { ROE (\%) } \\
\text { (Average for } \\
\text { Analyzed Period) }\end{array}$ & $\begin{array}{c}\text { Sustainability } \\
\text { Ranking (2021) }\end{array}$ & $\begin{array}{c}\text { Coefficient of } \\
\text { Correlation }\end{array}$ \\
\hline 1. & ProCredit & 11.39 & 3 & No relation \\
\hline 2. & Raiffeisen & 10.18 & 9 & Weak \\
\hline 3. & UniCredit & 9.91 & 4 & Mid \\
\hline 4. & Intesa & 9.67 & 1 & Mid \\
\hline 5. & AIK & 9.47 & 10 & Strong \\
\hline 6. & Opportunity & 9.3 & 5 & Strong \\
\hline 7. & Erste & 8 & 10 & Strong \\
\hline 8. & Komercijalna & 5.11 & 10 & No relation \\
\hline 9. & Euro & 3.01 & 10 & No relation \\
\hline 10. & Credit Agricole & 2.85 & 10 & No relation \\
\hline 11. & Direktna & 1.67 & 10 & Very strong relation \\
\hline 12. & Halk & 1.06 & & 2 \\
\hline Source: Authors' calculations and the information available on the websites of the analyzed banks [31-55].
\end{tabular}

Based on the analyzed data, it can be concluded that banks have developed the following strategies for the COVID-19 period:

(1) Security related to customer data and transactions;

(2) Further digital transformation, investment in new operational systems, further improvement of digital banking products, investment in new technologies and channels, easy access to the banking products, speeding up procedures, and efficiency improvements;

(3) Improvements in customer experience, a tailor-made approach when creating new products, and the adjustment of existing products to suit customer needs;

(4) Mergers and acquisitions in the market to increase market share (customer base);

(5) Further prosperity of all stakeholders through the further improvement of corporate governance, responsibility in the working environment, responsibility toward clients, responsibility in the supply chain, responsibility toward local communities, and responsibility toward the environment.

All of these strategies are in the function of obtaining and maintaining digitainability and profitability.

\section{Conclusions}

It can be concluded that all Serbian banks use some form of digitalization to create a more sustainable environment. In their annual reports, banks emphasize that there is an increasing number of customers who use digital banking products and that there has been a permanent improvement in the offered digital services and in the introduction of new ones, which are in accordance with customer needs. Furthermore, there is a visible trend of cooperation with other non-banking partners to expand banking offers for customers, 
i.e., all stakeholders are interested in (1) selling more products to existing customers, (2) acquiring new clients, and (3) generating additional profit. Finally, the role of the NBS is very important in promoting digital banking products and in providing financial market stability.

The research results show that $72 \%$ of the Serbian banking sector has some digitainability characteristics. These banks are Intesa, Erste, ProCredit, UniCredit, Opportunity, OTP, MOBI, NLB, Raiffeisen, Addico, ALTA, Credit Agricole, Direktna, Euro, Halk, Komercijalna, AIK, and Bank of China. The majority of the banks (almost 11, 61\%) respect the UN Global Compact Principles. Three banks have a transparent Code of Ethics. Seven banks have a unique approach to sustainability: (1) respecting the Global Alliance for Banking on Values (planet, people, and prosperity), (2) incorporating Corporate Social Responsibility, which includes Corporate Responsible Strategy, (3) focusing on Social Responsible Banking with the special attention to the environmental approach, (4) having a ESG committee on the holding level and that is in cooperation with UNICEF, and (5) using human banking. Two banks even support competition in organic production and in the generation of new ideas.

The analysis also shows that there is a direct relationship between the intangible investments and the net results; that is, when the value of intangible assets increases, the net result is increases, and vice versa. Therefore, the level of investment in digital transformation has a strong relationship with the net result of the banking sector in the Republic of Serbia. Compared to the previous study, it can be noticed that since 2018, there has been a strong relationship that has developed between investments in digital transformation and the achieved financial results. This is the result of the previous actions that were taken in order to be competitive in the market and new challenges caused by COVID-19, whereas at the same time, it was also important to obtain customer satisfaction in terms of data and transaction security. However, the situation is different at each bank. Fifteen traditional banks, or $60 \%$ of the Serbian banking sector (where 12 banks focus on digitainability (in italic below) and where seven of them are ranked in the list of top 10 banks according to the NBS (in italic and underlined below)), have positive ROE (the average for the analyzed period): ProCredit, Raiffeisen, UniCredit, Intesa, AIK, Opportunity, Erste, Komercijalna, Sber, Postanska, Euro, Credit Agricole, Direktna, Srpska, and Halk. The important finding is that Serbian banks who have chosen to focus on digitainability are profitable. Moreover, traditional banks are more profitable than virtual banks, but there is space for further cost improvement. Further results are in line with this. The Serbian banks that are profitable and that exhibit digitainability characteristics are in the no-relationship group, i.e., ProCredit, Erste, Euro, Credit Agricole, and Direktna. The banks with a strong relationship (Opportunity, Komercijalna, and AIK) are in second place. The banks with a medium relationship (UniCredit and Intesa) are in third place. Finally, the banks with the weak (Raiffeisen) and the very strong relationships (Halk) are in last place. It can be concluded that with respect to digitainability and profitability, the ranking of the banks can be expressed as follows: ProCredit, Raiffeisen, UniCredit, Intesa, AIK, Opportunity, Erste, Komercijalna, Euro, Credit Agricole, Direktna, and Halk.

Finally, based on the analyzed data, it can be concluded that the banks have the following strategies for the management of the COVID-19 pandemic and and beyond:

(1). Provide security, a criterion that is related to customer data and transactions;

(2). Expend digital transformation and innovation, including investment in new operational systems and new technologies, and to expand digital banking products and efficiency processes;

(3). Improve customer experience (to provide a tailor-made approach in the creation of new products and in adjusting existing products to fit customer needs;",

(4). Enhance the prosperity of all stakeholders through the further improvement of corporate governance, responsibility in the working environment, responsibility toward clients, responsibility in the supply chain, responsibility toward local communities, and responsibility toward the environment. 
Author Contributions: Conceptualization, N.S. and A.B.; methodology, L.B.; software, L.B.; validation, N.S., L.B. and A.B.; formal analysis, L.B.; investigation, A.B.; resources, N.S. and L.B.; data curation, L.B.; visualization, N.S and A.B.; supervision, N.S., L.B. and A.B.; project administration, A.B.; funding acquisition, A.B. All authors have read and agreed to the published version of the manuscript.

Funding: The research was done by Peter the Great St. Petersburg Polytechnic University and supported under the strategic academic leadership program 'Priority 2030' of the Russian Federation (Agreement 075-15-2021-1333 dated 30 September 2021).

Institutional Review Board Statement: Not applicable.

Informed Consent Statement: Not applicable.

Data Availability Statement: (1) National Bank of Serbia (NBS)—https://nbs.rs/en/finansijskeinstitucije/banke/bilans-stanja / (accessed on 15 June 2021), (2) United Nations Global CompactNetwork Serbia-https://www.unglobalcompact.org/engage-locally/europe/serbia (accessed on 19 June 2021).

Acknowledgments: The research is partially funded by the Ministry of Science and Higher Education of the Russian Federation under the strategic academic leadership program "Priority 2030" (Agreement No. 075-15-2021-1333, dated 30 September 2021).

Conflicts of Interest: The authors declare no conflict of interest.

\section{Appendix A}

Table A1. Overview of new digital banking/cooperation products in the Republic of Serbia (2021).

\begin{tabular}{|c|c|c|c|c|c|c|c|c|}
\hline \multirow[t]{2}{*}{ No. } & \multirow[t]{2}{*}{ Bank } & \multicolumn{2}{|c|}{$\begin{array}{c}\text { IPS-Possibility of Using } \\
\text { Instant Payments at Merchants' } \\
\text { Points of Sale (Retail) }\end{array}$} & \multicolumn{5}{|c|}{ In Cooperation with Non-Banking Partners } \\
\hline & & Show & QR Code & Union Pay & Pay Pal & Apple Pay & Moneget & $\begin{array}{c}\text { Payment } \\
\text { Institution }\end{array}$ \\
\hline 1 & Addico & + & + & & & & & + \\
\hline 2 & AIK & + & + & + & & & + & + \\
\hline 3 & ALTA & + & + & & & & & + \\
\hline 4 & API & & & + & & & & + \\
\hline 5 & Intesa & + & + & + & + & + & + & + \\
\hline 6. & Postanska & + & + & + & & & + & + \\
\hline 7 & Bank of China & & & & & & & \\
\hline 8 & Credit Agricole & + & + & & & & & + \\
\hline 9 & Direktna & + & + & + & & & + & + \\
\hline 10 & Expo & & & & & & & + \\
\hline 11. & Erste & + & + & & + & & + & + \\
\hline 12 & Euro & + & + & + & & & & + \\
\hline 13 & Halk & + & + & & & & & \\
\hline 14 & Komercijalna & + & + & + & & & & \\
\hline 15 & MIRA & & & & & & & \\
\hline 16 & MOBI & + & + & + & & & & \\
\hline 17 & MTS & & & & & & & + \\
\hline 18 & NLB & + & + & + & & & & + \\
\hline 19 & Opportunity & & & & & & & \\
\hline 20 & OTP & + & + & + & + & + & & + \\
\hline
\end{tabular}


Table A1. Cont.

\begin{tabular}{|c|c|c|c|c|c|c|c|c|}
\hline \multirow[t]{2}{*}{ No. } & \multirow[t]{2}{*}{ Bank } & \multicolumn{2}{|c|}{$\begin{array}{c}\text { IPS-Possibility of Using } \\
\text { Instant Payments at Merchants' } \\
\text { Points of Sale (Retail) }\end{array}$} & \multicolumn{5}{|c|}{ In Cooperation with Non-Banking Partners } \\
\hline & & Show & QR Code & Union Pay & Pay Pal & Apple Pay & Moneget & $\begin{array}{l}\text { Payment } \\
\text { Institution }\end{array}$ \\
\hline 21 & ProCredit & + & + & & & + & & \\
\hline 22 & Raiffiesen & + & + & + & & + & & + \\
\hline 23 & Sber & + & + & & & & + & + \\
\hline 24 & Srpska & & & & & & & \\
\hline 25 & UniCredit & + & + & + & & & & \\
\hline
\end{tabular}

Source: Prepared by the authors on the basis of the data available on the websites of the analyzed banks on 31 March 2021 [30-56,61], ABS [58], and Moneyget [62]. Note: '+ 'symbol marks the presence of the products.

Table A2. Overview of Serbian banks focusing on sustainability at the end of Q3 2021.

\begin{tabular}{|c|c|c|}
\hline No. & Bank & Sustainability Principles \\
\hline 1 & Intesa & $\begin{array}{l}\text { UN Global Compact-Network Serbia; the ten principles of UNDP Global Compact in the fields of } \\
\text { human and labor rights, environment and anti-corruption; the Code of Ethics, Principles of Human } \\
\text { Rights, Anti-Armament Policy, Environmental Policy, Political Parties Policy, Guidelines on } \\
\text { Prevention of Money Laundering and Financing Terrorism and relations with countries under } \\
\text { sanctions; reports about sustainability; takes care about all stakeholders; }\end{array}$ \\
\hline 2 & Erste & $\begin{array}{l}\text { UN Global Compact-Network Serbial; the Corporate Social Responsibility includes Corporate } \\
\text { Responsible Strategy (covering: corporate governance, responsibility towards clients, responsibility } \\
\text { in working environment, responsibility in supply chain, responsibility toward local communities, } \\
\text { responsibilities toward environment); reports about social responsible business; financial education; }\end{array}$ \\
\hline 3 & ProCredit & $\begin{array}{l}\text { Social responsible banking-relevant for the whole group; special attention to the environmental } \\
\text { approach (they have appropriate management structures on the holding and local level in order to } \\
\text { take care about the environment where they perform the business); transparent information about } \\
\text { mission and values (transparency, culture of open communication, social responsibility and tolerance, } \\
\text { high professional standards, personal integrity and communication/including the ethical codes); }\end{array}$ \\
\hline 4 & UniCredit & $\begin{array}{l}\text { Performing business in accordance with the UN Global Sustainable principles (through financing, } \\
\text { professional advices and networking; / cooperation with UNICEF and UniCredit foundation; they } \\
\text { have information about governance systems (including the code of conduct), corporate bodies and } \\
\text { management (ESG committee at the holding level); internal controls, remuneration and } \\
\text { internal dealings; }\end{array}$ \\
\hline 5 & Opportunity & $\begin{array}{l}\text { Performs business in accordance with UN Global sustainable principles-sustainable development } \\
\text { goals (UN Agenda 2030); the bank is a member of GABV (Global Alliance for Banking on Values); the } \\
\text { bank is specialized in microfinance, providing micro, rural, agro and SME loans and other financial } \\
\text { services to the clients in Serbia that can't ordinarily access financial services from traditional banks; it } \\
\text { reports to PCAF and GRI (please see below). PCAF (Partnership for Carbo Accounting Financials) is } \\
\text { a global partnership of financial institutions that work together to develop and implement a } \\
\text { harmonized approach to assess and disclose the greenhouse gas (GHG) emissions associated with } \\
\text { their loans and investments. The harmonized accounting approach provides financial institutions } \\
\text { with the starting point required to set science-based targets and align their portfolio with the Paris } \\
\text { Climate Agreement. } \\
\text { GRI (Global Reporting Initiative) is an independent international organization that helps businesses } \\
\text { and other organizations take responsibility for their impacts, providing them with a common global } \\
\text { language to communicate those impacts. GRI standards are globally recognized standards for } \\
\text { sustainability reporting that enable organizations and their stakeholders to take action and make } \\
\text { better decisions that create economic, environmental, and social benefits for all. The values of the } \\
\text { bank are: commitment, humility, respect, integrity, stewardship and transformation. }\end{array}$ \\
\hline 6 & OTP & $\begin{array}{l}\text { UN Global Compact-Network Serbia; supports the Serbian Olympic team; promotes the } \\
\text { competition Generator; }\end{array}$ \\
\hline 7 & MOBI & Human banking is their value; \\
\hline
\end{tabular}


Table A2. Cont.

\begin{tabular}{ccc}
\hline No. & Bank & Sustainability Principles \\
\hline 8 & NLB & Supports competition in organic production; \\
\hline 9 & Raiffeisen & Long term partnership with the non-for-profit sector; \\
\hline 10 & Addico & UN Global Compact-Network Serbia \\
\hline 11 & ALTA & UN Global Compact-Network Serbia \\
\hline 12 & Credit Agricole & UN Global Compact-Network Serbia \\
\hline 13 & Direktna & UN Global Compact-Network Serbia \\
\hline 14 & Euro & UN Global Compact- Network Serbia; investment in IT classrooms in primary schools in Serbia; \\
\hline 15 & Halk & Corporate values and customers' satisfaction; \\
\hline 16 & Komercijalna & UN Global Compact-Network Serbia; \\
\hline 17 & AIK & Focus on financial health of their customers; \\
\hline 18 & Bank of China & Donation of masks to Serbian hospitals; focus on health of their employees; \\
\hline
\end{tabular}

Source: Authors prepared the table based on the data available on the websites of the analyzed banks on 31 March 2021 [30-56,61], ABS [58], and the UN Global Compact [6].

Table A3. Overview of Serbian banks with respect to the relationship between intangible assets and net profit.

\begin{tabular}{|c|c|c|c|c|}
\hline \multicolumn{3}{|c|}{$\begin{array}{l}\text { Coefficient of Correlation } \\
\text { (No. of Banks) }\end{array}$} & \multirow{2}{*}{$\begin{array}{c}\text { DP (Digitainability Caracteristics } \\
\text { and Profitable) in } 2020 \\
\text { No, of Banks }\end{array}$} & \multirow[t]{2}{*}{ Comment } \\
\hline Type of Relation & 2020 & $3 q 2018$ & & \\
\hline No & 8 & 6 & 5 & $\begin{array}{l}\text { ProCredit: 3rd place sustainability, 1st place ROE; } \\
\text { Erste: 2nd place sustainability, 7th place ROE; } \\
\text { Euro: 10th place sustainability, 9th place ROE; } \\
\text { Credit Agricole: 10th place sustainability, 10th } \\
\text { place ROE; } \\
\text { Direktna: 10th place sustainability, 11th place ROE; }\end{array}$ \\
\hline Weak & 2 & 5 & 1 & Raiffeisen: 9th place sustainability, 2nd place ROE \\
\hline Medium & 10 & 8 & 2 & $\begin{array}{l}\text { Intesa: 1st place sustainability, 4th place ROE; } \\
\text { UniCredit: 4th place sustainability, 3rd place ROE; }\end{array}$ \\
\hline Strong & 4 & 5 & 3 & $\begin{array}{l}\text { Opportunity: 5th place sustainability, 6th place ROE; } \\
\text { Komercijalna:10th place sustainability, 8th place ROE; } \\
\text { AIK: 11th place sustainability, 5th place ROE; }\end{array}$ \\
\hline Very strong & 1 & 3 & 1 & Halk: 10th place sustainability, 12th place ROE \\
\hline
\end{tabular}

Source: Authors' calculations based on the information available on the websites of the analyzed banks and the NBS [30-56,63].

\section{References}

1. Lichtenthaler, U. Digitainability: The Combined Effects of the Megatrends Digitalization and Sustainability. JIM 2021, 9, 64-80. [CrossRef]

2. Sa, M.J.; Santos, A.I.; Serpa, S.; Ferreira, C.M. Digitainability- Digital Competences Post-COVID-19 for a Sustainable Society. Sustainability 2021, 13, 9564. [CrossRef]

3. Kriebel, J.; Debener, J. Measuring the Effect of Digitalization Efforts on Bank Performance. In Academy of Management Annual Meeting Proceedings; Academy of Management: New York, NY, USA, 2020; pp. 1-43. [CrossRef]

4. Kitsios, F.; Giatsidis, I.; Kamarioutou, M. Digital Transformation and Strategy in the Banking Sector: Evaluating the Acceptance Rate of E-Services. J. Open Innov. Technol. Mark. Complex 2021, 7, 168. [CrossRef]

5. Gupta, S.; Motlagh, M.; Rhyner, J. The Digitalization Sustainability Matrix: A Participatory Research Tool for Investigating Digitainability. Sustainability 2020, 12, 9283. [CrossRef]

6. Agboola, M.; Awobajo, K.; Oluwatobi, S.; Akinbode, M.; Fagbohun, M.; Esse, U.; Segun-Adeniran, C.; Asaolu, A.; Betek, C. Effect of digitalization on the performance of commercial banks in Nigeria. In Proceedings of the International Conference on Energy and Sustainable Environment, Covenant University, Nigeria, 18-20 June 2019; Volume 331, pp. 1-8. [CrossRef]

7. Zuo, L.; Strauss, J.; Zuo, L. The Digitalization Transformation of Commercial Banks and Its Impact on Sustainable Efficiency Improvements through Investment in Science and Technology. Sustainability 2021, 13, 1028. [CrossRef]

8. Aguayo, F.Z.; Ślusarczyk, B. The Risks of Banking Services' Digitalization: The Practice of Diversification and Sustainable Development Goals. Sustainability 2020, 12, 4040. [CrossRef] 
9. Ivanova, O.; Korobeinikova, L.S.; Rising, I.E.; Sysoeva, E.F. The Main Directions and Tools of Banking Digitalization. In Digital Economy: Complexity and Variety vs. Rationality; Springer: Cham, Switzerland, 2019; pp. 510-516.

10. Niemand, T.; Coen Rigtering, J.P.; Kallmünzer, A.; Kraus, S.; Maalaouie, A. Digitalization in the financial industry: A contingency approach of entrepreneurial orientation and strategic vision on digitalization. Eur. Manag. J. 2021, 39, 317-326. [CrossRef]

11. Roy, M.; Sarked, M.A.S.; Parvez, S. Sustainability in Banking Industry: Which way to move? ASA Univ. Rev. 2015, 9, 53-59.

12. Kumar, K.; Prakash, A. Managing sustainability in banking: Extent of sustainable banking adaptations of banking sector in India. Environ. Dev. Sustain. 2020, 22, 5199-5217. [CrossRef]

13. Korzeb, Z.; Samaniego-Medina. Sustainability Performance. A Comparative Analysis in the Polish Banking Sector. Sustainability 2019, 11, 653. [CrossRef]

14. Weber, O. Corporate Sustainability and Financial Performance of Chinese banks. Sustain. Account. Manag. Policy J. 2017, 8, 358-385. [CrossRef]

15. Jan, A.; Marimuthu, M.; Pisol bin Mohd, M.; Isa, M. The nexus of sustainability practices and financial performance: From the perspective of Islamic banking. J. Clean Prod. 2019, 228, 703-717. [CrossRef]

16. Olmo, B.T.; Saiz, M.C.; Azofra, S.S. Sustainable Banking, Market Power, and Efficiency: Effects on Banks' Profitability and Risk. Sustainability 2021, 13, 1298. [CrossRef]

17. Buallay, A. Is sustainability reporting (ESG) associated with performance? Evidence from the European banking sector. Manag. Environ. Qual. 2019, 3, 98-115. [CrossRef]

18. Bhaskaran, R.K.; Sujit, K.S.; Mongia, S. Linkage between performance and sustainability initiatives in banking sector-An empirical examination. Int. J. Product. Perform. Manag. 2021. ahead of print. [CrossRef]

19. Forcadell, F.J.; Aracil, E.; Ubeda, F. The Impact of Corporate Sustainability and Digitalization on International Banks' Performance. Contemp. Issues Bank. 2020, 11, 18-27. [CrossRef]

20. Forcadell, F.J.; Aracil, E.; Ubeda, F. Using reputation for corporate sustainability to tackle banks digitalization challenges. Bus. Strategy Environ. 2020, 29, 2181-2193. [CrossRef]

21. Paulet, E.; Mavoori, H. Conventional banks and Fintechs: How digitization has transformed both models. J. Bus. Strategy 2020, 41, 19-29. [CrossRef]

22. Bank for International Settlement. Trending Topics. Available online: www.bis.org (accessed on 15 October 2021).

23. Vesic, T. Analize i Perspektive Razvoja Bankarskog Sektora u Zemaljama Zapadnog Balkana sa Posebnim Osvrtom na Predvidjanje Kretanja Problematicnih Kredita. Ph.D. Thesis, Singidunum University, Belgrade, Serbia, 2021.

24. Stakic, N.; Barjaktarovic, L.; Singh, D. Key Determinants of Financial Inclusion: An Empirical Evidence from Western Balkan Countries. In Financial Inclusion in Emerging Markets: A Road Map for Sustainable Growth; Palgrave Macmillan: Singapore, 2021; pp, 49-69. [CrossRef]

25. European Commission. European Neighborhood Policy and Enlargement Negotiations. Available online: https:/ / ec.europa eu/neighbourhood-enlargement/news/2021-enlargement-package-european-commission-assesses-and-sets-out-reformpriorities-western_en (accessed on 13 November 2021).

26. Loncar, D. Inercija Zabluda: Ucestale Grekske Menadzera, 1st ed.; D. Loncar: Belgrade, Serbia, 2020; pp. 1-317.

27. Taleb, N. The Black Swan: The Impact of the Highly Improbable, 2nd ed.; Random House Publishing: London, UK, $2010 ;$ pp. 1-444.

28. Stakic, N.; Barjaktarovic, L. Osnovi Finansijskog Inzenjeringa, 1st ed.; Singidunum University: Belgrade, Serbia, $2021 ;$ pp. 1-249.

29. Barjaktarović, L.; Stefanovic, N. What is the Effect of Intangible Assets on Earning of the Serbian Banking Sector? Industija 2019, 47, 61-75. [CrossRef]

30. Financial Statement of Banks-NBS. Available online: https://nbs.rs/en/finansijske-institucije/banke/bilans-stanja/ (accessed on 15 June 2021).

31. Addico Bank a.d. Beograd. Digital Banking \& About Us. Available online: https://www.addiko.rs/ (accessed on 31 May 2021).

32. Agoindustrijsko Komercijalna Banka AIK, A.D. Beograd. Electronic Banking \& About Us. Available online: www.aikbanka.rs (accessed on 31 May 2021).

33. Alta Banka a.d. Beograd. E-Banking \& About Us. Available online: http:/ / www.altabanka.rs (accessed on 31 May 2021).

34. Api BANK a.d. Beograd. E-Banking \& About Us. Available online: https://www.apibank.rs/elektronsko-bankarstvo/ (accessed on 31 May 2021).

35. Banca Intesa a.d. Beograd. E-Banking \& About Us. Available online: https://www.bancaintesa.rs/stanovnistvo/elektronskobankarstvo.28.html (accessed on 31 May 2021).

36. Bank of China a.d. Srbija. Online Banking \& About Us. Available online: http://www.bankofchina.com/rs/ (accessed on 31 May 2021).

37. Banka Poštanska Štedionica a.d. Beograd. Electronic Banking \& About Us. Available online: https://www.posted.co.rs (accessed on 31 May 2021).

38. Crédit Agricole Banka Srbija a.d. Novi Sad. Electronic Banking \& About Us. Available online: https://www.creditagricole.rs / elektronsko-bankarstvo/elektronsko-bankarstvo.144.html (accessed on 31 May 2021).

39. Direktna Banka a.d. Kragujevac. E-Banking \& About Us. Available online: https://www.direktnabanka.rs (accessed on 31 May 2021).

40. Erste Bank a.d. Novi Sad. Digital Banking\& About Us. Available online: https:/ / www.erstebank.rs/sr (accessed on 31 May 2021). 
41. Eurobank a.d. Beograd. Digital Banking \& About Us. Available online: www.eurobank.rs/digitalno-bankarstvo/e-banking--eurobank.1739.html (accessed on 31 May 2021).

42. Expo Bank a.d. Beograd. E-Banking \& About Us. Available online: http://www.expobank.rs/index.php/sr/ebanking (accessed on 31 May 2021).

43. Halk Banka a.d. Beograd. Electronic Banking \& About Us. Available online: http://www.halkbank.rs/opste-informacije-e-bank nspx (accessed on 31 May 2021).

44. Komercijalna Banka a.d. Beograd. E-Services \& About Us. Available online: https://www.kombank.com/sr/e-servisi] (accessed on 31 May 2021).

45. Mirabank a.d. Beograd. E-Banking \& About Us. Available online: https://www.mirabankserbia.com/what-we-offer/executivebanking/e-banking (accessed on 31 May 2021).

46. Mobi Banka a.d. Beograd. Online Banking \& About Us. Available online: http://www.mobibanka.rs (accessed on 31 May 2021).

47. MTS Banka a.d. Beograd. mBanking \& About Us. Available online: https://mtsbanka.rs/sr-Latn-RS/stanovnistvo/mBanking (accessed on 31 May 2021).

48. NLB Banka a.d. Beograd. Corporate. Available online: https://www.nlb.rs/strana/16421/privreda (accessed on 17 June 2021).

49. Opportunity Banka a.d. Novi Sad. E-Banking \& About Us. 2021. Available online: http://www.obs.rs/biznis/elektronskobankarstvo/ (accessed on 31 May 2021).

50. OTP Banka Srbija a.d. Novi Sad. Electronic Banking \& About Us. Available online: https://www.otpbanka.rs/elektronskobankarstvo (accessed on 31 May 2021).

51. ProCredit Bank a.d. Beograd. Business \& About Us. Available online: https://www.procreditbank.rs/index.php/sr/biznis/ elektronsko-bankarstvo/internet-bankarstvo (accessed on 31 May 2021).

52. Raiffeisen Bank a.d. Beograd. Digital Banking \& About Us. Available online: https://www.raiffeisenbank.rs (accessed on 31 May 2021).

53. Sber Bank Srbija a.d. Beograd. Digital Banking \& About Us. Available online: https://www.sberbank.rs/stanovnistvo (accessed on 31 May 2021).

54. Srpska Banka a.d. Beograd. E-Banking. Available online: http://http://www.srpskabanka.rs/e-bankarstvo/index.html (accessed on 31 May 2021).

55. UniCredit Bank a.d. Beograd. Bank on the Button \& About Us. Available online: https:/ /www.unicreditbank.rs/ (accessed on 31 May 2021).

56. List of Banks. NBS. Available online: https://nbs.rs/en/finansijske-institucije/banke/spisak-banaka/ (accessed on 15 June 2021).

57. National Bank of Serbia. Bankarski Sektor u Srbiji: Izveštaj za II tromesecje 2020. godine. Available online: http:/ /www.nbs.rs / internet/cirilica/55/index.html (accessed on 15 June 2021).

58. Association of Serbian Banks (ABS). Serbian Banking in 2020; Banking-Special Issue; ASB: Belgrade, Serbia, 2020 ; pp. 1-63.

59. Zelenović, V.; Radovic, M.; Vitomir, J. Perspektiva bankarstva u svetlu digitalizacije. In Proceedings of the-Jahorina Business Forum 2020, Jahorina, Serbia, 23-25 March 2020; pp. 189-198, ISSN 2303-8969.

60. United Nations Global Compact-Network Serbia. Available online: https://www.unglobalcompact.org/engage-locally/ europe/serbia (accessed on 19 June 2021).

61. National Bank of Serbia. Registar Platnih Institucija. Available online: https://nbs.rs/sr_RS/finansijske-institucije/pi-ien/ registar-pi/ (accessed on 15 June 2021).

62. MoneyGet. Internacionalna Mreza Bankomata. Available online: www.moneyget.rs (accessed on 15 June 2021).

63. United Nations. The Sustainable Development Goals. Available online: https://www.un.org/sustainabledevelopment/ sustainable-development-goals (accessed on 19 June 2021). 